Saulo Jorge Téo ${ }^{1+}$, Sebastião do Amaral Machado², Afonso Figueiredo Filho², Margarida Tomé $^{3}$

\section{GENERAL HEIGHT-DIAMETER EQUATION WITH BIOLOGICAL ATTRIBUTES FOR Pinus taeda L. STANDS}

Keywords:

Height-diameter relationship

h-d model

Biological consistency

Stand variables

Historic:

Received 10/08/2017

Accepted 20/I I/2017

Palavras chave:

Relação hipsométrica

Curvas h-d

Consistência biológica

Variáveis do povoamento

${ }^{+}$Correspondence: sauloteo@yahoo.com.br
ABSTRACT: The aim of this study was to develop an equation with biological attributes and general applicability, to represent the height-diameter relationship for Pinus taeda L. stands, with and without thinning, in the Middle West region of Santa Catarina state, Brazil. The data came from 652 permanent plots, with 428 to $740 \mathrm{~m}^{2}$, located in forest stands with ages ranging from 4.6 to 35.2 years, in which the total heights of about $20 \%$ by Harrison, Michailoff, Prodan and Stoffels \& Van Soest were fitted with their parameters linear function of stand variables, based on the Gauss-Newton algorithm. In general, the Harrison model, fitted with the parameter linear function of age $(t)$, site index $(S)$, coefficient of variation of the tree diameters in the plot $\left(\mathrm{CV}_{\mathrm{d}}\right)$ and basal area of the plot $(G)$, showed the best statistical performance to represent the height-diameter relationship, biological consistency and general applicability for stands of Pinus taeda.

\section{RELAÇÃO HIPSOMÉTRICA GERAL COM ATRIBUTOS BIOLÓGICOS PARA POVOAMENTOS DE Pinus taeda L.}

RESUMO: O objetivo deste estudo foi desenvolver uma equação com atributos biológicos e aplicabilidade geral, para representar a relação hipsométrica de povoamentos de Pinus taeda L., com e sem desbaste, na região Meio Oeste do estado de Santa Catarina. Os dados são provenientes de 652 parcelas permanentes, de 428 a $740 \mathrm{~m}^{2}$, localizadas em povoamentos florestais com idades variando de 4,6 a 35,2 anos, em que foram medidas as alturas totais de cerca de $20 \%$ das árvores, além das árvores dominantes. As funções de Harrison, Michailoff, Prodan e Stoffels e Van Soest foram ajustadas com seus parâmetros função linear de variáveis do povoamento, baseado no algoritmo Gauss-Newton. De maneira geral, o modelo de Harrison, ajustado com o coeficiente função linear da idade $(t)$, índice de sítio $(S)$, coeficiente de variação dos diâmetros das árvores da parcela $\left(C V_{d}\right)$ e área basal da parcela $(G)$, mostrou o melhor desempenho estatístico para representar a relação hipsométrica, consistência biológica e aplicabilidade geral para povoamentos de Pinus taeda. of the trees were measured, in addition to the dominant trees. The functions developed 


\section{INTRODUCTION}

The total height $(h)$ refers to the linear distance from ground level to the upper tip of the tree crown, through its main axis. It is the most used height measurement, more objective and less subject to errors of judgment (BATISTA et al., 20l4), recording of total height is preferred to merchantable lengths on permanent sample plots when tree-growth measurements are based on periodic measurements of the same trees.

The variable height is important for the volume calculation methods and for the measure of height and volume increment of trees; in the estimation methods, the height is independent variable in volume equations and taper functions; and, at forest stand level, the average height of dominant trees $\left(h_{\text {dom }}\right)$ is used as indicator of the productive capacity of forest land (MACHADO; FIGUEIREDO FILHO, 2009).

In an individual-tree growth model, a tree height growth equation or a static height-diameter equation should be added as an additional component in order to predict total and merchantable volume growth (TOMÉ, 1988; LEDUC; GOELZ, 2009; CRECENTE-CAMPO et al., 20I0). The use of hypsometric relation was adopted as a sub-model in the individual-tree growth models by several authors, as Harrison et al. (1986), Tomé (1988), Palahí et al. (2008), Paulo and Tomé (2009), Alegria and Tomé (20I3), Juma et al. (20I4) and Miranda (20I6). The lack of successive height measurements of the same tree is commonly forcing the use of compatible height projection equation and height-diameter prediction equation in the individual-tree growth models (TOMÉ, 1988; SOARES; TOMÉ, 2002).

Then, some technique for estimating height is essential for individual-tree growth models, furthermore are indispensable for most forest inventories. While the diameter at breast height $(d)$ of standing trees in a sample plot is easily obtained at low cost for most forest species, height measurement is considerably more difficult and costly to collect, especially in tall stands, dense stands and containing irregularly shaped tree stems and crowns, or on sloping land (SANQUETTA et al., 20I4).

The height-diameter relationship is influenced by several factors, such as sociological position, forest site quality, age, density, sylvicultural treatments and species characteristics (CARDOSO et al. 1989; BARROS et al., 2002; BARTOSZECK et al., 2004; MACHADO et al., $20 \mathrm{II})$. Due to the sensibility of the height-diameter relationship to these various factors, in many situations, some develop a local equation for each sample plot of the forest inventory (BARROS et al., 2002), which is a costly and time-consuming procedure (VARGASLARRETA et al., 2009). The local height-diameter equations are normally only dependent on tree diameter at breast height (d) and can be applied to the stand where the data were gathered. To evaluate the influence of several factors on the height-diameter relationship, it is necessary to study the possibility of applying general equations, which allow the estimation of tree height in different social positions, ages, in stands of different site qualities and densities, eliminating the work of fitting and selection height-diameter equations for each sample plot (BARROS et al., 2002). These equations are a function of tree diameter, dominant height $\left(\mathrm{h}_{\mathrm{dom}}\right)$, age $(t)$, density and other stand variables that can be applied at the regional level (TOMÉ, I988; SOARES; TOMÉ, 2002; VARGASLARRETA et al., 2009).

In Brazil, some general height-diameter relationships were represented by empirical models, without biological characteristics, some with extensive mathematical equations (BARROS et al., 2002; FIGUEIREDO FILHO et al, 20I0), which according to Tomé (1988), they suggest the existence of multicollinearity. On the other hand, Harrison et al. (1986) and Tomé (1988) deduced functions in order to guarantee they assume a biologically appropriate shape to represent height-diameter relationship. Fitting Harrison et al. (1986) and Tomé (1988) equations with their parameters expressed as a linear combination of stand variables is an alternative model approach instead the empirical extensive equations to develop general height-diameter relationship.

The biologically appropriate characteristics of the functions used to represent the h-d relationship, both local and general, were: I) be an increasing function; II) to present the height increment per diameter unit decreases with increasing diameter; III) to present an asymptote; IV) to present the asymptote near to the $\left.h_{\text {dom }} ; V\right)$ to restrict the origin of the function at the point $(d, h)=(0, I .3)$ (HARRISON et al., 1986; TOMÉ, I988; SOARES; TOMÉ, 2002; TOMÉ et al., 2007; PAULO; TOMÉ, 2009). Tomé (1988), Soares and Tomé (2002), Tomé et al. (2007) and Paulo and Tomé (2009) tested functions with biological behavior to represent the general height-diameter relationship, in which their parameters were expressed as function of forest stand variables such as $t$, quadratic mean diameter $\left(d_{g}\right)$, maximum diameter of the sample plot $\left(d_{\max }\right)$, number of trees $(N)$, basal area $(G)$, dominant height $\left(h_{\text {dom }}\right)$ and site index $(S)$.

Thus, the objective in this work was to develop an equation with biological attributes and general 
applicability to represent the height-diameter relationship of Pinus taeda L. stands in the Middle West region of Santa Catarina state, Brazil.

\section{MATERIAL AND METHODS}

The study area is in the municipalities of Caçador, Lebon Régis, Macieira, Rio das Antas, Santa Cecília e Timbó Grande, all of them in Santa Catarina state, Brazil. According to the Köppen classification, the study region climate is humid temperate (Cfb type), with annual average temperature of $16.5^{\circ} \mathrm{C}$, annual average rainfall of $1,600 \mathrm{~mm}$, annual average relative humidity of $77 \%$ and occurrence of 26 night-frosts per year, in average. The original vegetation in the study region was the Montane Araucaria Forest, the main soils classes of the study area are Cambisols and Nitsols. The first one is typical of mountainous regions, presents great variation of depth and drainage characteristics, and can be rocky or gravelly. The second is deep, clayey, acid, with low basis saturation (IBGE, 2007).

The data came from 652 sample plots installed in pure evenaged stands of Pinus taeda, with area ranging from 428 to $740 \mathrm{~m}^{2}$ of periodic reinventory with permanent plots, which were distributed according to a restricted random sampling design, in which the strata were constituted by the management units of the forest company. All Pinus taeda trees in the sample plots had their circumference at breast height (c) measured by a tape. The total heights ( $h$ ) of approximately $20 \%$ of the trees were measured using the Haglö ${ }^{\circledR}$ Vertex III hypsometer, in addition to the dominant trees of each sample plot, defined as the 100 thickest trees per hectare, without multiple stems or defects in the crown.

The database was split into two sub-samples: 590 sample plots constitute the fitting sample and 62 the validation sample (Table I). The validation sample were selected randomly, restricted to each company's management units and site classes, according to the anamorphic site index curves developed by Téo et al. (20I I), for Pinus taeda, in the same study area.

The candidate function by Harrison et al. (1986) (Table 2) was formed by expressing the parameters in Meyer's equation (Equation I) as function of $h_{\text {dom }}$, aiming to obtain a function to represent the general heightdiameter relationship for several forest stands, where: $h$ total height $(m) ; d=$ diameter at breast height $(\mathrm{cm}) ; a, b$ parameters of the function.

$h=1.3+\left\{a\left[1-e^{\left(-b^{*} d\right)}\right]\right\}$
TABLE I Tree and stand variables for the fitting and validation data of the general height-diameter functions for Pinus taeda L., in the Middle West region of Santa Catarina state, Brazil.

\begin{tabular}{|c|c|c|c|}
\hline & Variable & Fitting & Validation \\
\hline \multirow{14}{*}{ Stand } & Mean age (years) & 12.34 & 12.75 \\
\hline & Minimum age (years) & 4.60 & 4.60 \\
\hline & Maximum age (years) & 35.20 & 35.10 \\
\hline & Minimum reinventory number & 2 & 2 \\
\hline & Maximum reinventory number & 12 & 12 \\
\hline & Mean dominant height (m) & 18.30 & 18.49 \\
\hline & Minimum dominant height $(\mathrm{m})$ & 6.47 & 7.13 \\
\hline & Maximum dominant height (m) & 42.68 & 41.42 \\
\hline & Mean basal area $\left(\mathrm{m}^{2} \cdot \mathrm{ha}^{-1}\right)$ & 46.38 & 45.20 \\
\hline & Minimum basal area $\left(\mathrm{m}^{2} \cdot \mathrm{ha}^{-1}\right)$ & 13.86 & 8.99 \\
\hline & Maximum basal area $\left(\mathrm{m}^{2} \cdot \mathrm{ha}^{-1}\right)$ & 77.57 & 70.89 \\
\hline & Mean number of trees (trees $\cdot \mathrm{ha}^{-1}$ ) & 1305 & 1338 \\
\hline & Minimum number of trees (trees $\cdot \mathrm{ha}^{-1}$ ) & $27 \mid$ & 320 \\
\hline & Maximum number of trees (trees $\cdot \mathrm{ha}^{-1}$ ) & 2220 & 2158 \\
\hline \multirow{6}{*}{ Tree } & Mean diameter at breast height $(\mathrm{cm})$ & 22.37 & 22.35 \\
\hline & Minimum diameter at breast height $(\mathrm{cm})$ & 3.18 & 3.50 \\
\hline & Maximum diameter at breast height $(\mathrm{cm})$ & 69.07 & 66.21 \\
\hline & Mean total height $(\mathrm{m})$ & 15.15 & 15.27 \\
\hline & Minimum total height (m) & 2.40 & 3.20 \\
\hline & Maximum total height $(\mathrm{m})$ & 44.90 & 43.20 \\
\hline
\end{tabular}

The parameter $a$ of the Equation I, which represents the asymptote, was expressed as function of $h_{\text {dom }}$ to ensure that the asymptote is near to $h_{\text {dom }}$ (can be superior). The parameter $b$ of the Equation I expressed as function of $h_{\text {dom }}$ guarantees that the height growth rate is smaller for the greatest dominant heights.

Tomé ( 1988) deduced the three last general heightdiameter functions presented in Table 2 restricting to the point $\left(\mathrm{d}_{\mathrm{dom}}, \mathrm{h}_{\mathrm{dom}}\right)$. The models by Michailoff, Prodan and Stoffels \& Van Soest were used as the starting point to the final formulation (Table 2), which the equations depend on only one parameter. All the candidate functions were fitted with their parameters expressed as a linear combination of stand variables. The models by Michailoff, Prodan and Stoffels \& Van Soest have only one parameter $a$ expressed as a linear combination of stand variables, so they were denominated Michailoff_a, Prodan_a and Stoffels \& Van Soest_a. The parameters $a, b$ and $c$ in model by Harrison et al. (1986) also were expressed as a combination of stand variables and was denominated Harrison_a, Harrison_b and Harrison_c, respectively.

First of all, the stand variables which the parameters of the height-diameter functions were expressed as a linear combination were organized into different categories: I) age; II) site productivity; III) sample plot; IV) stand density.

The height-diameter relationship depends on the age of the forest stand (CARDOSO et al., 1989; BARROS et al., 2002; BARTOSZECK et al., 2004), which is recommended as an independent variable of general 
TABLE 2 Candidate functions to model the general height-diameter relationship for Pinus taeda L.

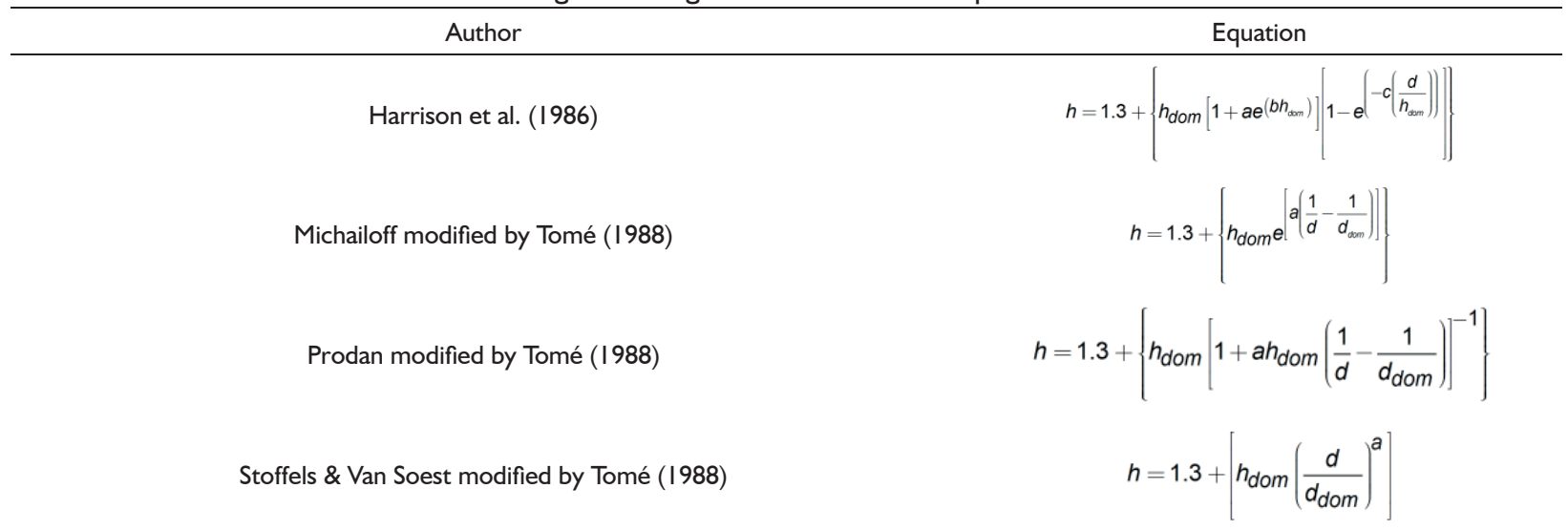

Where: $\mathrm{h}=$ total height $(\mathrm{m}) ; \mathrm{d}=$ diameter at breast height $(\mathrm{cm})$; $\mathrm{h} \_$dom $=$dominant height $(\mathrm{m})$; d_dom $=$ dominant diameter $(\mathrm{cm})$; $a, b, c=$ parameters; $=\mathrm{euler}$ 's constant (2.7).

height-diameter equations (FIGUEIREDO FILHO et al., 20I0). In this research, we consider the age of the forest stand $(t)$, in years.

Another forest stand characteristic that influences the height-diameter relationship is the site productivity (CARDOSO et al., 1989; BARROS et al., 2002). The effect of the site productivity was measured by the site index, expressed by the dominant height $\left(h_{\text {dom }}\right)$ at the base age of 20 years, estimated by the algebraic difference approach (ADA) equation of Hossfeld IV/McDill-Amateis fitted by Téo (2017) (Equation 2), where: dominant height at final age $(\mathrm{m})$; dominant height at initial age $(\mathrm{m})$; initial age (years); final age (years).

$\hat{h}_{\text {dom } 2}=\frac{57.017}{1-\left[1-\left(\frac{57.017}{h_{\text {dom }}}\right)\right] *\left(\frac{t_{1}}{t_{2}}\right)^{1.2457}}$

The sample plot variables tested were: mean diameter $(\bar{d})$, in $\mathrm{cm}$; coefficient of variation of the diameters $\left(C V_{d}\right)$, in \%; quadratic mean diameter $\left(d_{g}\right)$, in $\mathrm{cm}$; maximum diameter of the sample plot $\left(d_{\max }\right)$.

The height-diameter relationship tends to be more sloping for the stands with higher densities, once the competition effects growth more in diameter than in height (BARTOSZECK et al., 2004). The variables of the stand density category were: the basal area $(G)$, in $\mathrm{m}^{2} \cdot \mathrm{ha}^{-1}$; number of trees $(N)$, in trees $\cdot \mathrm{ha}^{-1}$; the transformations of the number of trees $N^{-1}$ and $100 \cdot N^{-1}$, and the Wilson Factor $\left(F_{w}=100 /\left(h_{\text {dom }} * \sqrt{ } N\right)\right)($ WILSON, 195I).

The stand variables selection was based on multiple linear regression, where total height $(h)$ was the dependent variable and the stand variables of each category was the regressor variables. The selection of the best regressor variables set within each category was made by the PROC REG procedure of the SAS ${ }^{\circledR}$
University Edition, based on the rsquare variable selection method. The final selection was based on multiple linear regression with the best stand variable of each category as the regressor variables, where we analyze the significance of the parameters (Student's value) and the presence of collinearity based on the values of the variance inflation factor (VIF), where values up to 10 were accepted (MYERS, 1986). The number of variables was restricted by the presence of one of each abovementioned category.

The candidate functions (Table 2) were fitted for 83,130 values of total height $(h)$ and diameter at breast height ( $d$ ) (fitting sample). The parameter estimation of these non-linear functions was made by the least squares method of the PROC NLIN procedure of the $\mathrm{SAS}^{\circledR}$ University Edition, based on the Gauss-Newton iterative method. The studies of Harrison et al. (1986) and Tomé (1988) were used to obtain the initial values for the parameters of the height-diameter functions. The final estimates of the parameters of the height-diameter functions, and a $95 \%$ confidence band, should exclude zero, indicating that there are only non-zero values for the parameters and then they are always significant.

The initial selection phase of the height-diameter functions, the criteria for comparing models were: adjusted coefficient of determination $\left(R_{a}^{2}\right)$; standard error of estimate (RMSE\%), in percentage; mean of the residuals $(M)$; mean of the absolute residuals $(M A)$; and analysis of studentized residuals. The presence of heteroscedasticity associated with error term of the models was checked by plotting the studentized residuals against the predicted total height value ( $h$ '). When heteroscedasticity was detected, the parameter estimation was made by weighted least squares method, which the weights tested were several stand variables 
(basal area, number of trees, mean diameter, and others), as well as their transformations and combinations, assuming that the error variance is an exponential function of some explanatory variables (PARRESOL, 1993). A graph of studentized residuals plotted against their expected values under normality, the so called QQplot, will display a straight line with a slope of $\mathrm{I}$ in the ideal situation, when the error distribution are normal. The studentized residuals are ranked in increasing order and are plotted against the cumulative probability of a normal distribution. Once detected the non-normality was overcome using iteratively reweighted least squares regression, Huber (1964) function was selected as the influence function to reduce the influence of data points containing large studentized residuals $(>+2$ and $<-2)$ on fit, according to Myers (1986).

In addition to statistics $R_{a}^{2}, R M S E \%, M, M A$, we computed statistics based on prediction sum of squares (PRESS) residuals: mean of the PRESS residuals $\left(M_{\text {press }}\right)$; mean of the absolute PRESS residuals $\left(M A_{\text {press }}\right)$. Consider a set of data in which the th observation is set aside from the sample and the remaining $n^{-1}$ observations are used to estimate the coefficients for the candidate model. The procedure continues until all the observations have been removed, one at a time, and thus the candidate model is fitted times, and will have PRESS residuals $\left(e_{i,-i}\right)$ (Equation 3), where: PRESS residual for th observation; observed dependent variable for th observation; predicted dependent variable for th observation, but was set aside and not used in obtaining the coefficients.

$\mathrm{e}_{i,-i}=Y_{i}-\hat{Y}_{i,-i}$

The validation sample has $8,80 \mathrm{I}$ values of total height $(h)$ and diameter at breast height $(d)$. The validation statistics was: model efficiency (ME) (VANCLAY and SKOVSGAARD, 1997) (Equation 4); mean of the residuals $(M)$; mean of the absolute residuals $(M A)$. To perform the cross-validation for the candidate functions, first the fitting sample was used to fitting the model and estimating the parameters, while the validation sample was used to estimate the responses of the model. After this, the validation sample was used for fitting while the fitting sample was used for calculating the statistics, where: observed dependent variable for th observation; predicted dependent variable for th observation; mean of observed values.

$$
M E=1-\left[\frac{\sum_{i=1}^{n}\left(Y_{i}-\hat{Y}_{i}\right)^{2}}{\sum_{i=1}^{n}\left(Y_{i}-\nabla\right)^{2}}\right]
$$

The best performance model in the previous fitting and cross-validation phases was submitted to the analysis of $M_{\text {press }}$ and $M A_{\text {press }}$ by classes of age $(t)$, site index $(S)$, coefficient of variation of the diameters $\left(C V_{d}\right)$, and basal area $(G)$. After data splitting for cross-validation, the model finally adopted was fitted using the entire data set, including fitting sample and validation sample, making use of all information.

\section{RESULTS AND DISCUSSION}

The set of stand variables which the parameters of the height-diameter functions were expressed as a linear combination were: age $(t)$, in years; site index $(S)$, in meters; coefficient of variation of the diameters $\left(\mathrm{CV}_{d}\right)$, in \%; and basal area $(G)$, in $\mathrm{m}^{2} \cdot \mathrm{ha}^{-1}$.

The estimates of the parameters were significant $(\alpha=0,05)$ for almost all height-diameter equations, with the parameters expressed as a linear combination of the stand variables mentioned. However, Michailoff_a and Harrison_a equations presented the coefficient corresponding to the basal area not significant in the linear combination of the parameter $a$, so these equations were fitted without the basal area.

The Harrison et al. (1986) model showed the best statistical performance to represent the height-diameter relationship for Pinus taeda (Table 3). For the different versions of Harrison equation, Harrison_c presented superiority for all selection statistics, except for the bias $\left(M\right.$ and $\left.M_{\text {press }}\right)$, where Harrison_b showed the values of and nearest to zero (Table 3).

TABLE 3 Selection statistics of the general height-diameter equations for Pinus taeda L., in the Middle West region of Santa Catarina state, Brazil.

\begin{tabular}{ccccccc}
\hline Equation & $R_{a}^{2}$ & $\begin{array}{c}\text { RMSE } \\
\%\end{array}$ & $M$ & $M A$ & $M_{\text {PRESS }}$ & $M_{\text {PRESS }}$ \\
\hline Harrison_a & 0.9799 & 6.19 & -0.0109 & 0.7085 & -0.0047 & 0.6450 \\
Harrison_b & 0.9795 & 6.26 & 0.0062 & 0.7262 & -0.0043 & 0.6445 \\
Harrison_c & 0.9817 & 5.91 & -0.0180 & 0.6731 & -0.0063 & 0.6402 \\
Michailoff_a & 0.9538 & 9.39 & -0.7200 & 1.1542 & -0.5785 & 1.0140 \\
Prodan_a & 0.9523 & 9.54 & -0.7176 & 1.1667 & -0.5846 & 1.0223 \\
$\begin{array}{c}\text { Stoffels \&Van } \\
\text { Soest_a }\end{array}$ & 0.9568 & 9.08 & -0.6693 & 1.0976 & -0.5593 & 1.0001 \\
\hline
\end{tabular}

Where: $R_{a}^{2}=$ adjusted coefficient of determination; $R M S E \%=$ standard error of estimate; $M=$ mean of the residuals $(\mathrm{m}) ; M A=$ mean of the absolute residuals $(\mathrm{m}) ; M_{\text {PRESS }}=$ mean of the PRESS residuals $(\mathrm{m}) ; M A_{\text {PRESS }}=$ mean of the absolute PRESS residuals $(\mathrm{m})$

The Michailoff, Prodan and Stoffels \& Van Soest equations modified by Tomé (1988) showed very similar statistical performance, but always with less precision and more bias when compared to the statistical performance of the different versions of Harrison equation (Table 
3). All height-diameter equations fitted in this study presented negative bias ( $M$ and $\left.M_{\text {press }}\right)$, except the value for the Harrison_b equation.

The different versions of Harrison equation presented selection statistics very similar to those reported by Soares and Tomé (2002), for Harrison equation with the parameter $a$ expressed as a linear combination of stand variables, for Eucalyptus globulus Labill. in Portugal. The Michailoff, Prodan and Stoffels \& Van Soest equations presented fitting and precision similar to those reported by Tomé (1988), also for Eucalyptus globulus. Using mixedeffects model approach, Coble and Lee (20I I) concluded that the height-diameter equations that includes standlevel independent variables best predicts total height in East Texas (USA) Pinus taeda trees.

The different versions of Harrison equation fitted by generalized least squares method produced studentized residuals without heteroscedasticity, however with evidences of non-normality of the residuals, especially with large residuals (in magnitude) at both extremes of the distribution of errors. Therefore, the parameter estimation was made by reweighted least squares regression, with Huber (1964) method, in which the distribution of residuals exhibited homoscedasticity and normality (Figure I). The studentized residual plots of the different versions of Harrison equation demonstrated the

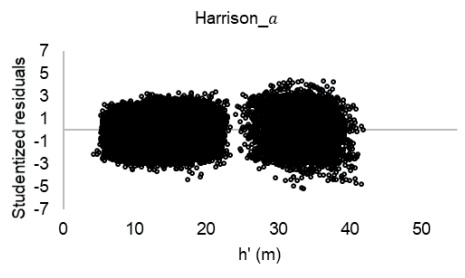

Harrison_ $b$

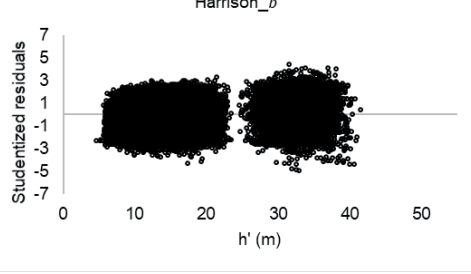

Harrison_c

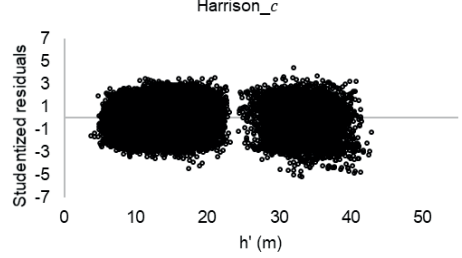

FIGURE I Analysis of studentized residuals for different versions of Harrison equation, with the parameters expressed as a linear combination of the stand variables, to represent general height-diameter relationship for Pinus taeda L., in the Middle West region of Santa Catarina state, Brazil. characteristics of the database, which doesn't have Pinus taeda trees with ages ranging from 13.8 and 23.2 years (Figure I). Although studentized residual aren't plotted against the age, this characteristic can be observed by the scarcity, or absence of values of predicted total height ( $\left.h^{\prime}\right)$ around 23 and 24 meters (Figure I).

The Michailoff and Stoffels \& Van Soest equations after parameter estimation by reweighted least squares regression, with Huber (1964) method, showed homoscedasticity and normality of the distribution of residuals (Figure 2). On the other hand, the Prodan equation still presented marked negative residuals, even after the application of the Huber (1964) method.

There is an underestimation trend for the smallest total heights estimated by the Michailoff_ equation (Figure 2). The Michailoff, Prodan and Stoffels \& Van Soest equations tended to overestimate for the biggest values of estimate total height, mainly by the Prodan_a equation.

Similarly to what happened with the selection statistics, the Harrison et al. (1986) model, fitted with its parameters linear function of stand variables, showed the best performance for validation statistics to heightdiameter relationship of Pinus taeda (Table 4). And again, the Harrison_c equation presented the best results for validation statistics, except for bias $\left(M_{2-1}\right)$ calculated for the fitting sample, with the parameters estimated by the validation sample.

The Michailoff, Prodan and Stoffels \& Van Soest equations, modified by Tomé (1988), showed very similar validation statistics, always with less precision and more bias, when compared to the different versions of the Harrison et al. (1986) equation (Table 4).

According to the selection statistics (Table 3), analysis of studentized residuals (Figures I and 2) and validation statistics (Table 4), the most appropriate equation to represent the height-diameter relationship of Pinus taeda was Harrison_c. Finally, the bias and accuracy of total height estimates by classes of age, site index, coefficient of variation of the diameters, and basal area were analyzed using PRESS residuals $\left(e_{i,-i}\right)$.

Modest values of $M_{\text {press }}$ for ages ranging from 5 to 14 years and from 23 to 31 years indicate less bias of total height estimates by Harrison_c equation (Figure 3 ). However, there are more expressive values of $M_{\text {press }}$ for ages ranging from 32 to 35 years, which indicate an overestimate tendency of total heights of Pinus taeda (Figure 3). The increase in $M A_{\text {press }}$ values according to age indicate less precision of total height estimates for the older trees (Figure 3). 

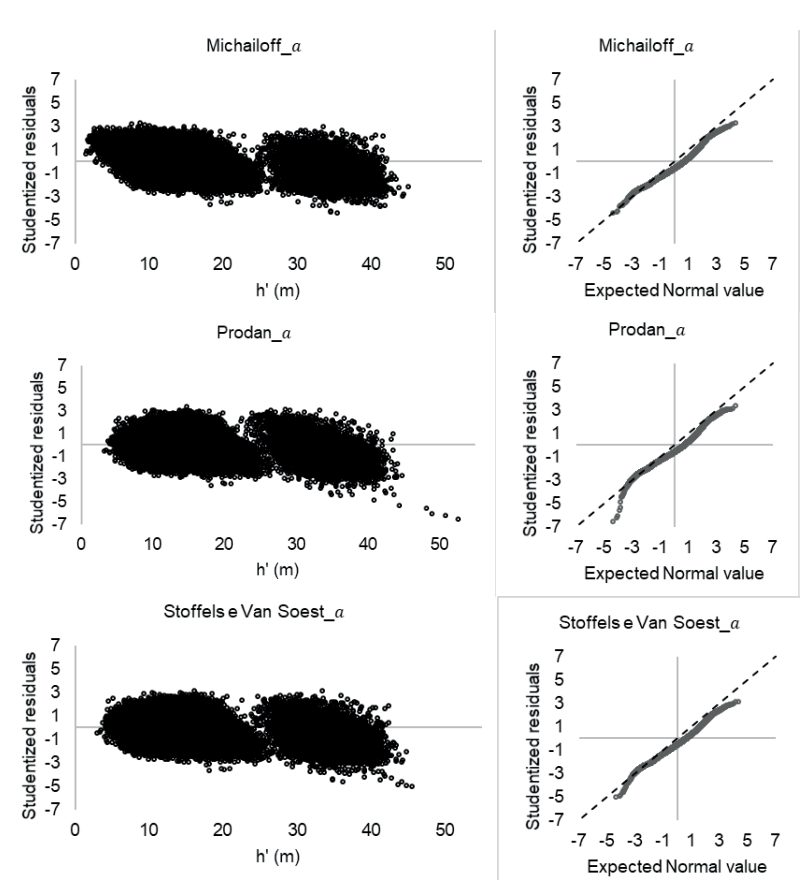

FIGURE 2 Analysis of studentized residuals for Michailoff, Prodan and Stoffels \& Van Soest equations, with the parameters expressed as a linear combination of the stand variables, to represent general heightdiameter relationship for Pinus taeda L., in the Middle West region of Santa Catarina state, Brazil.

About the site index, the most marked $M_{\text {press }}$ values occur for the smallest and largest site index classes, indicating negative bias (Figure 3). There is also an increase of $M A_{\text {press }}$ values for the smallest and largest site index classes, indicating a slight reduction in accuracy (Figure 3). The changes in statistics $M_{\text {press }}$ and $M A_{\text {press }}$ were less expressive for the different site index classes than different ages.

The Harrison_ equation presented small bias $\left(M_{\text {press }}\right)$ for the estimated total heights in most classes of coefficient of variation of the diameters $\left(C V_{d}\right)$, except for the classes 27 and 31\%, which presented negative bias

TABLE 4 Cross-validation statistics of the general heightdiameter equations for Pinus taeda L., in the Middle West region of Santa Catarina state, Brazil..

\begin{tabular}{ccccccc}
\hline Equation & $M_{(1-2)}$ & $M_{(1-2)}$ & $M_{(1-2)}$ & $M_{(2-1)}$ & $M_{(2-1)}$ & $M_{(2-1)}$ \\
\hline Harrison_a & 0.9812 & 0.0100 & 0.7146 & 0.9796 & -0.0460 & 0.7218 \\
Harrison_b & 0.9812 & 0.0204 & 0.7231 & 0.9793 & -0.0185 & 0.7326 \\
Harrison_c & 0.9841 & 0.0057 & 0.6623 & 0.9817 & -0.0457 & 0.6762 \\
Michailoff_a & 0.9598 & -0.6797 & 1.1276 & 0.9538 & -0.7414 & $\mathrm{I} .1569$ \\
Prodan_a & 0.9576 & -0.6922 & $\mathrm{I} .1469$ & 0.9524 & -0.7455 & $\mathrm{I} .1764$ \\
Stoffels e Van Soest_a & 0.9622 & -0.6504 & $\mathrm{I} .0727$ & 0.9568 & -0.6756 & $\mathrm{I} .1006$ \\
\hline
\end{tabular}

Where: $M E=$ model efficiency; $M=$ mean of the residuals; $M A=$ mean of the absolute residuals; $\mathrm{I}-2=$ using fitting sample for estimation of parameters and validation sample for calculation of errors; $2-I=$ using validation sample for estimation of parameters and fitting sample for calculation of errors.
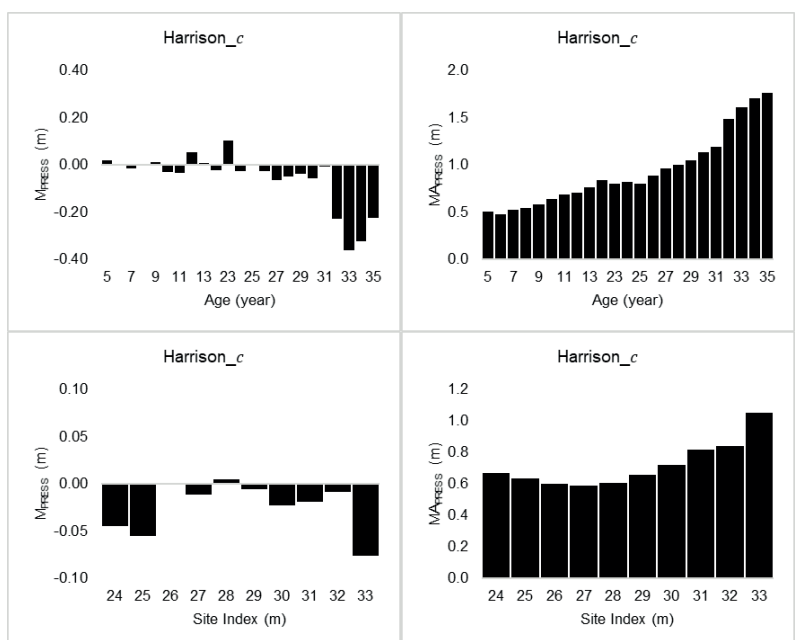

FIGURE 3 Mean of the PRESS residuals $\left(M_{\text {PRESS }}\right)$ and mean of the absolute PRESS residuals $\left(M A_{\text {PRESS }}\right)$ by classes of age and site index, for Harrison_c equation to represent the general height-diameter relationship for Pinus taeda L., in the Middle West region of Santa Catarina state, Brazil.

(Figure 4). The $M A_{\text {press }}$ values indicate similar accuracy for most $C V_{d}$ classes, except for $31 \%$ (Figure 4).

The Harrison_c equation produced total height estimates with low bias $\left(M_{\text {press }}\right)$, except for the smallest basal area class, which presented positive bias (Figure 4). The $M A_{\text {press }}$ values point lower precision of the height estimates for the larger basal area classes (Figure 4).

$\left.\hat{h}=1.3+\left\{h_{\text {dom }}\left[1-0.86339 e^{\left(-0.17538 h_{\text {som }}\right)}\right]\left[1-e^{\left(-c\left(\frac{d}{h_{\text {osm }}}\right)\right.}\right]\right)\right\}$

The Harrison_c equation selected to estimate total height $(h)$ of Pinus taeda, fitted using the entire data set, including fitting sample and validation sample, is given by equation 5 , where: $c=0.30393+0.04328 t+0.02985 S$ 0.005 I 2CVd+0.00340G; $\hat{h}=$ estimated total height $(\mathrm{m})$; $d=$ diameter at breast height $(\mathrm{cm}) ; h_{\text {dom }}=$ dominant height $(m) ; t=$ stand age (year); $S=$ site index $(m) ; C V_{d}=$ coefficient of variation of the diameters (\%); $G=$ basal area $\left(\mathrm{m}^{2} \cdot h \mathrm{a}^{-1}\right)$; Euler's constant (2.7I).

Soares and Tomé (2002) also selected the Harrison et al. (1986) function, however with the parameter $a$ expressed as a linear combination of stand variables, to represent the height-diameter relationship of Eucalyptus globulus in Portugal. A negative value for $a$ in combination with the additive constant (I.3) results in an asymptote near dominant height $\left(h_{\text {dom }}\right)$, to the height-diameter relationship for Pinus taeda. The rate parameter $c$, which guarantees that the height increase rate is smaller for the 

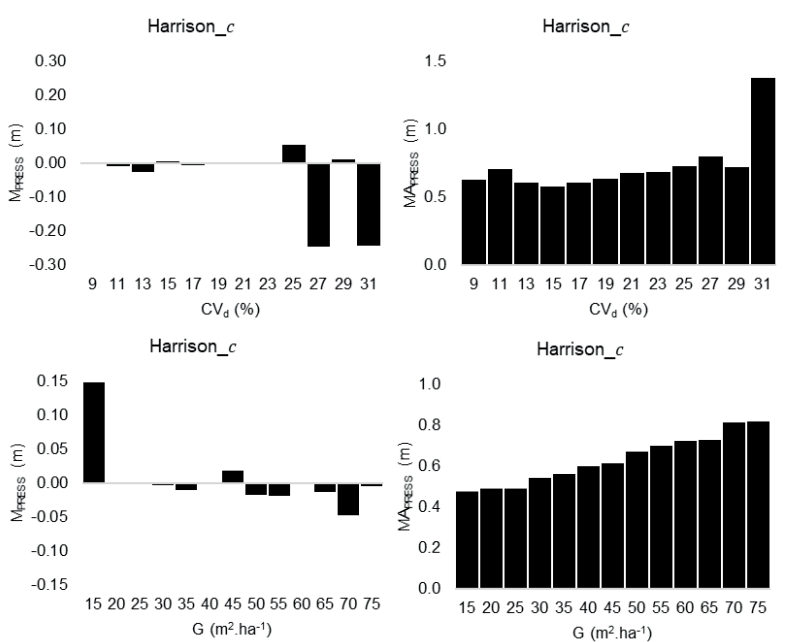

FIGURE 4 Mean of the PRESS residuals $\left(M_{\text {PRESS }}\right)$ and mean of the absolute PRESS residuals ( $M A_{\text {PRESS }}$ ) by classes of coefficient of variation of the diameters, and basal area, for Harrison_c equation to represent the general height-diameter relationship for Pinus taeda L., in the Middle West region of Santa Catarina state, Brazil.

greatest diameter at breast height (d), was expressed as a combination of stand variables: age $(t)$, site index $(S)$, coefficient of variation of the diameters $\left(C V_{d}\right)$, and basal area $(G)$. This formulation allows to describe the differences in height-diameter relationship of Pinus taeda, under the effect of these several stand variables, as well as, ensure general applicability to the equation 5 .

The equation 5 was used to generate height estimates of Pinus taeda trees with ages ranging from 5 to 35 years and site index of 22, 28 and $34 \mathrm{~m}$ (Figure $5)$. The total height estimates of Pinus taeda for different ages have been made using average site index (28 m) and average values of dominant height $\left(h_{\text {dom }}\right), C V_{d}$ and $G$, computed from the data set of each analyzed age (Figure $5)$. The simulations of the site index effect on heightdiameter relationship were made using age of 10 years, average values of $C V_{d}$ and $G$, computed for these age, and values of $h_{\text {dom }}$ estimated by equation 2 (Figure 5).

For young Pinus taeda trees, the height-diameter curves presented steeper and more curvilinear tendency, however, with increasing age, it has become flatter (Figure 5). Barros et al. (2002) reported the same pattern when analyzing the height-diameter relationship for thinned Pinus oocarpa Schiede stands, with ages ranging from 5 to 25 years. Cardoso et al. (1989) also found similar patterns of the height-diameter curves of Pinus taeda stands with different ages, in Central and Southwest region of Paraná state, Brazil. Although fixed intervals of 5 years were used to describe the effect of age on height-diameter relationship of Pinus taeda, there is a decrease in the distance between height-diameter curves with increasing age (Figure 5). Probably because of the reduce in height and diameter growth in old ages, making the changes of the height-diameter curves become very small.

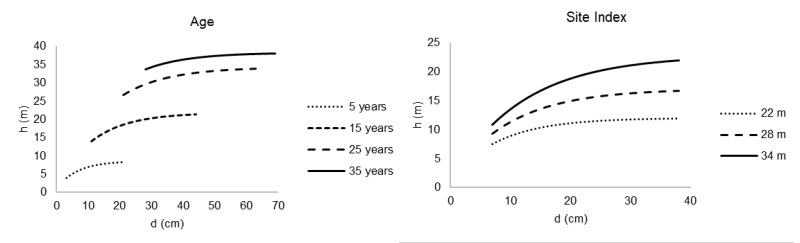

FIGURE 5 Age and site index effect on general heightdiameter relationship, represented by Harrison_c equation, for Pinus taeda L., in the Middle West region of Santa Catarina state, Brazil.

In more productive sites, the height-diameter curves of Pinus taeda were steeper and presented larger asymptotes than in poor sites (Figure 5). Cardoso et al. (1989) e Bartoszeck et al. (2004) also reported steeper height-diameter curves for more productive sites of Pinus taeda and Mimosa scabrella Bentham, in Paraná state, Brazil.

\section{CONCLUSIONS}

The Harrison et al. (1986) function, fitted with the parameter expressed as a linear combination of age $(t)$, site index $(S)$, coefficient of variation of the tree diameters in the plot $\left(C V_{d}\right)$ and basal area of the plot $(G)$, showed the best statistical performance to represent the height-diameter relationship of Pinus taeda L., in the Middle West region of Santa Catarina state, Brazil.

The fitting of the Harrison et al. (1986) model, with its parameter linear function of forest stand variables, allowed the development of a height-diameter equation with good statistical performance, biological consistency and general applicability for stands of Pinus taeda. By allying these characteristics, the height-diameter equation presented here is innovative when compared with the extensive empirical equations commonly used in Brazil.

\section{REFERENCES}

ALEGRIA, C.; TOMÉ, M. A tree distance-dependent growth and yield model for naturally regenerated pure unevenaged maritime pine stands in central inland of Portugal. Annals of Forest Science, v. 70, n. 3, p. 26I-276, 20 I 3.

BARROS, D. A. de; MACHADO, S. A.; ACERBI JÚNIOR, F. W.; SCOLFORO, J. R. S. Comportamento de modelos hipsométricos tradicionais e genéricos para plantações de Pinus oocarpa em diferentes tratamentos. Boletim de Pesquisa Florestal, n. 45, p. 3-28, 2002. 
BARTOSZECK, A. C. P. S; MACHADO, S. A.; FIGUEIREDO FILHO, A.; OLIVEIRA, E. B. de. Dinâmica da relação hipsométrica em função da idade, do sítio e da densidade inicial de povoamentos de bracatinga da região metropolitana de Curitiba, PR. Revista Árvore, v. 28, n. 4, p. 5I7-533, 2004.

BATISTA, J. L. F; COUTO, H. T. Z. do; SILVA FILHO, D. F. da. Quantificação de recursos florestais: árvores, arvoredos e florestas. Oficinas de Textos, 20I4. 384p.

CARDOSO, D. J.; MACHADO, S. A.; ROSOT, N. C.; EMERENCIANO, D. B. Avaliação da influência dos fatores idade e sítio na relação hipsométrica para Pinus taeda nas regiões central e sudoeste do estado do Paraná. Floresta, v. 19, n. I, p. 96-II5, 1989.

COBLE, D. W.; LEE, Y. A mixed-effects height-diameter model for individual loblolly and slash pine trees in East Texas. Southern Journal of Applied Forestry, v. 35, n. I, p. I2-I7, 20II.

CRECENTE-CAMPO, F.; SOARES, P.; TOMÉ, M.; DIÉGUEZARANDA, $U$. Modelling annual individual-tree growth and mortality of Scots pine with data obtained at irregular measurement intervals and containing missing observations. Forest Ecology and Management, v. 260, n. I I, p. I9651974, 2010.

FIGUEIREDO FILHO, A.; DIAS, A. N.; KOHLER, S. V.; VERUSSA, A. A.; CHIQUETTO, A. L. Evolution of the hypsometric relationship in Araucaria angustifolia plantations in the mid-south region of Paraná state. Cerne, v. 16, n. 3, p. 347-357, 2010.

HARRISON, W. C.; BURK, T. E.; BECK, D. E. Individual tree basal area increment and total height equations for appalachian mixed hardwoods after thinning. Southern Journal of Applied Forestry, v. 10, n. 2, p. 99-104, 1986.

HUBER, P. J. Robust estimation of a location parameter. The Annals of Mathematical Statistics, v. 35, n. I, p. 73I0I, 1964.

IBGE-INSTITUTO BRASILEIRO DE GEOGRAFIA E ESTATÍSTICA. Manuais técnicos em geociências: Manual técnico de pedologia. n. 4. 2 ed. IBGE, 2007. 300p.

JUMA, R.; PUKKALA, T.; MIGUEL, S.; MUCHIRI, M. Evaluation of different approaches to individual tree growth and survival modelling using data collected at irregular intervals - a case study for Pinus patula in Kenya. Forest Ecosystems, v. I, p. I4(I3), 20 I4.

LEDUC, D.; GOELZ, J. A height-diameter curve for longleaf pine plantations in the Gulf Coastal Plain. Southern Journal of Applied Forestry, v. 33, n. 4, p. I64- I70, 2009.

MACHADO, S. A.; BARROS, D. A.; SCOLFORO, J. R. S.; ACERBI JÚNIOR, F. W. The effects of successive thinnings on the hypsometric function for Pinus oocarpa stands. Floresta, v. 4I, n. 2, p. 397-406, 201 I.
MACHADO, S. A.; FIGUEIREDO FILHO, A. Dendrometria. 2 ed. UNICENTRO, 2009. 316p.

MIRANDA, R. O. V. Modelagem de árvores individuais para povoamentos não desbastados de Pinus taeda $L$. 2016. I68 p. PhD thesis Universidade Federal do Paraná, Curitiba, 2016.

MYERS, R. H. Classical and modern regression with applications. Duxbury Press, 1986. 359p.

PALAHÍ, M.; PUKKALA, T.; KASIMIADIS, D.; POIRAZIDIS, K.; PAPAGEORGIOU, A. C. Modelling site quality and individual-tree growth in pure and mixed Pinus brutia stands in north-east Greece. Annals of Forest Science, v. 65, n. 5 , p. 50I-5I4, 2008.

PARRESOL, B. R. Modeling multiplicative error variance: an example predicting tree diameter from stump dimensions in baldcypress. Forest Science, v. 39, n. 4, p. 670-679, 1993.

PAULO, J. A.; TOMÉ, M. An individual tree growth model for juvenile cork oak stands in southern Portugal. Silva Lusitana, v. I7, n. I, p. 27-38, 2009.

SANQUETTA, C. R.; CORTE, A. P. D.; ROGRIGUES, A. L.; WATZLAWICK, L. F. Inventários florestais: planejamento e execução. 3 ed. Multi-Graphic Gráfica e Editora, 20I4. 406p.

SOARES, P.; TOMÉ, M. Height-diameter equation for first rotation eucalypt plantations in Portugal. Forest Ecology and Management, v. I66, n. I-3, p. 99-109, 2002.

TÉO, S. J.; BRESSAN, D. R.; COSTA, R. H. Uso de modelos estatísticos para classificação de sítios em povoamentos de Pinus taeda na região de Caçador - SC. Floresta, v. 4I, n. I, p. I79-I88, 20II.

TÉO, S. J. Modelagem do crescimento e produção de árvore individual independente da distância, para Pinus taeda L., na região meio oeste do estado de Santa Catarina. 2017. 272 p. PhD thesis Universidade Federal do Paraná, Curitiba, 2017.

TOMÉ, M. M. B. B. T. Modelação do crescimento da árvore individual em povoamentos de Eucalyptus globulus Labill. ( ${ }^{a}$ rotação) região Centro de Portugal. 1988. 277 p. PhD thesis Instituto Superior de Agronomia, Lisboa, 1988.

TOMÉ, M.; RIBEIRO, F; FAIAS, S. Relação hipsométrica geral para Eucalyptus globulus Labill. em Portugal. Silva Lusitana, v. I5, n. I, p. 4I-55, 2007.

VANCLAY, J. K.; SKOVSGAARD, J. P. Evaluating forest growth models. Ecological Modelling, v. 98, n. I, p. I- I2, 1997.

VARGAS-LARRETA, B.; CASTEDO-DORADO, F.; ÁLVAREZGONZÁLEZ, J. G.; BARRIO-ANTA, M.; CRUZ-COBOS, F. A generalized height-diameter model with random coefficients for uneven-aged stands in El Salto, Durango (Mexico). Forestry, v. 82, n. 4, p. 445-462, 2009.

WILSON, F. G. Control of growing stock in even-aged stands of conifers. Journal of Forestry, v. 49, n. 10, p. 692-695, 195 I. 